\title{
The spatial development concept of the agro- industrial complex in the Western macro-district of the Krasnoyarsk region
}

\author{
Alexander Tsvettsykh ${ }^{1,2, *}$, Igor Polukhin ${ }^{1}$, Oksana Polyushkevich ${ }^{3}$ and Elena Shtark $^{4}$ \\ ${ }^{1}$ Reshetnev Siberian State University of Science and Technology, Krasnoyarsky Rabochy Av., 41, \\ 660037 Krasnoyarsk, Russia \\ ${ }^{2}$ Krasnoyarsk State Agrarian University, Lenin Str., 117, 660049 Krasnoyarsk, Russia \\ ${ }^{3}$ Irkutsk State University, Karl Marx Str., 1, 664003 Irkutsk, Russia \\ ${ }^{4}$ Professor V.F. Voino-Yasenetsky Krasnoyarsk State Medical University, Partizan Zheleznyak Str, 1, \\ 660022 Krasnoyarsk, Russia
}

\begin{abstract}
Improving the territorial location of the agro-industrial complex on the basis of considering the peculiarities of the labor, natural and climatic potential of municipal districts is an important factor in increasing the sustainability of rural development. In the present article, a study of the social, natural-climatic and economic-geographical prerequisites for the specialization of the agro-industrial complex of the Western macro-district was conducted. The results of the study were the definition of spatial development concept for the agro-industrial complex based on the formation and development of specialized agricultural zones in the Western macrodistrict of the Krasnoyarsk region. It was proved that in the conditions of a market economy, the need for scientifically based specialization of rural areas, the development of inter-district economic relations, the creation of combined industries that provide deep processing of agricultural raw materials becomes particularly relevant.
\end{abstract}

\section{Introduction}

The object of the study is the historically developing, hierarchically subordinated territorial ecological and socio-economic systems of the Western macro-district of the Krasnoyarsk region. The agro-industrial complex of the Western macro-district has considerable export potential, which can be used as a factor of sustainable development of rural areas. Geographically, the Western macro-district of the Krasnoyarsk region includes Nazarovo, Achinsk, Bogotol, Bolsheuluysk, Kozulsky, Novoselovo, Biryluss, Tyukhtetsk, Sharypovo municipal districts and 4 cities.

A large number of foreign [1-6] and Russian [7-24] works are devoted to the problem of spatial placement and development of agricultural enterprises. At the same time, the theoretical and methodological aspects of the justification for the spatial location of the agroindustrial complex in a market economy that ensures uniform, differentiated development of

\footnotetext{
* Corresponding author: tsvettsykhalex@mail.ru
} 
rural areas based on the rational using territorial resources, natural and climatic potential of the municipal districts of Siberia remain insufficiently studied.

The main purpose of the study was to substantiate the conceptual vision of the spatial development priorities of the agro-industrial complex in the Western macro-district based on the consideration of external and internal factors. To achieve this goal, it was necessary to solve the following tasks:

- analysis of social, natural-climatic and economic-geographical prerequisites for the spatial development of the agro-industrial complex in the Western macro-district of the Krasnoyarsk region [14-16];

- analysis of the institutional prerequisites for the spatial development of the agroindustrial complex in the Western macro-district of the Krasnoyarsk region [17-19].

The solution of the set tasks required the use of special methods for studying the regional economy: system and factor approaches, methods of physical-geographical and economicgeographical zoning.

\section{Methods and types of the spatial development concept of the agro-industrial complex}

Special methods of regional studies were required to achieve the objectives. To study the essence of the spatial development of productive forces required the use of a monographic method. To determine the peculiarities of the concepts of spatial development of the productive forces of the agro-industrial complex, it is necessary to use the historical-genetic method, systemic and factor approaches, deductive and inductive methods.

When highlighting and evaluating the patterns and factors of spatial development of the productive forces of the agro-industrial complex of the Krasnoyarsk Territory, the statistical method, methods of economic zoning (physical-geographical and economic-geographical zoning, the method of energy-production cycles), cartographic and balance methods were applied. Based on the results of the analytical review of the concepts of the spatial development of productive forces, we will draw several conclusions:

- all the considered concepts of spatial development complement each other, therefore, their synthesis is necessary for the preparation of a new scheme of spatial development of the agro-industrial complex of the Krasnoyarsk Territory;

- the need to create prerequisites for import substitution and the development of export potential in order to ensure the sustainable development of the rural territories of the region requires the improvement of the territorial organization of the productive forces of the agroindustrial complex of the Krasnoyarsk Territory;

- it is necessary to develop new approaches to the deployment of the productive forces of the agro-industrial complex of the Krasnoyarsk Territory based on the study and consideration of the entire system of factors, especially social, environmental, transport and innovative.

These conclusions are necessary to determine the prerequisites for the formation of an author's methodological approach to the spatial development of the productive forces of the agro-industrial complex of the Krasnoyarsk Territory. Objective processes of polarization of the economic space pose certain threats to the equitable development of rural areas. The concentration of the population in a limited number of urbanized regions is actively continuing. These regions delay significant public investment in infrastructure development. The decline in the population of the regions of Siberia and the Far East is increasing. Therefore, the continuation of the policy of "growth poles" can have negative consequences for Russia's national security. 


\section{Results and Discussion}

The study of the socio-economic processes of the municipal districts' development of the Western macro-district of the Krasnoyarsk region will be carried out on the basis of the using statistical information of the municipalities in the Krasnoyarsk region. To do this, we will calculate the growth rate of the most significant socio-economic indicators highlighted in Table 1.

Table 1. Socio-economic indicators of municipal districts' development in the Western macro-district of the Krasnoyarsk region.

\begin{tabular}{|c|c|c|c|c|c|}
\hline \multirow[b]{2}{*}{$\begin{array}{l}\text { Socio-economic } \\
\text { indicators }\end{array}$} & \multirow[b]{2}{*}{2010} & \multirow[b]{2}{*}{2015} & \multirow[b]{2}{*}{2019} & \multicolumn{2}{|c|}{ Growth rate, \% } \\
\hline & & & & $\begin{array}{l}2015 / \\
2010\end{array}$ & $\begin{array}{l}2019 / 2 \\
015\end{array}$ \\
\hline $\begin{array}{l}\text { Average annual } \\
\text { number of permanent } \\
\text { population, people }\end{array}$ & $\begin{array}{c}39006 \\
7\end{array}$ & $\begin{array}{c}37620 \\
7\end{array}$ & $\begin{array}{c}36528 \\
7\end{array}$ & -3.55 & -2.90 \\
\hline $\begin{array}{l}\text { Migration growth, } \\
\text { person }\end{array}$ & -2109 & -1912 & -901 & -9.34 & -52.87 \\
\hline $\begin{array}{l}\text { Acreage of crops in } \\
\text { farms of all } \\
\text { categories, hectares }\end{array}$ & $\begin{array}{c}49755 \\
3.58\end{array}$ & $\begin{array}{c}53285 \\
7.89\end{array}$ & $\begin{array}{c}49997 \\
7.68\end{array}$ & 7.09 & -6.17 \\
\hline $\begin{array}{l}\text { Production of } \\
\text { agricultural products } \\
\text { (crop production, } \\
\text { animal husbandry), } \\
\text { thousand rubles }\end{array}$ & $\begin{array}{c}14958 \\
382\end{array}$ & $\begin{array}{c}24459 \\
841\end{array}$ & $\begin{array}{c}25781 \\
719\end{array}$ & 63.51 & 5.40 \\
\hline
\end{tabular}

The analysis of statistical information on socio-economic indicators of the municipal districts in the Western macro-district of the Krasnoyarsk region helps to formulate the following conclusions:

- for the period from 2010 to 2015, the greatest decrease in the average annual number of permanent population occurred in Sharypovo (-10.02\%), Biryluss $(-7.05 \%)$ and Novoselovo (-6.98 \%) municipalities in the period from 2015 to 2019 in - Bogotol (-8.60 $\%)$, Biriluss (-7.14\%), Achinsk (-7.06\%) municipal districts;

- the most significant decrease in the average annual resident population of the Western macro-districts was observed in the period from 2010 to $2015(-3.55 \%)$, in the period from 2015 to 2019, the decrease in the average annual resident population slowed to $2.90 \%$;

- for the period from 2010 to 2015, the highest rate of population outflow was observed in Achinsk (216.09\%), Kozulk (190\%) and Sharypovo (110\%) municipal districts, in the period from 2015 to 2019 in Bolsheuluysk (479.16\%), Nazarovo (396\%) municipal districts;

- for the entire studied period, the Western macro-district has experienced a negative migration increase in the population, by the end of 2019, there was a slowdown in the outflow of population from 2109 to 901 people;

- for the period from 2010 to 2015, the sown area of agricultural crops in farms of all categories increased by $7.09 \%$ (or 35.304 .31 hectares), for the period from 2015 to 2019 , the sown area decreased by $6.17 \%$ (or 32.880 .21 hectares), the maximum increase in the sown area of agricultural crops is observed in the Achinsk municipal district (in the period from 2010 to $2015-57.98 \%$ ), (in the period from 2015 to $2019-37.11 \%$ );

- for the entire studied period, there was an increase in agricultural production, while the rate of its increase slowed down (from $63.51 \%$ in the period $2010-2015$ to $5.40 \%$ in the period 2015-2019).

At the next stage of the study, an analysis of the physical, geographical and agro-climatic features of the municipal territories for the Western macro-district of the Krasnoyarsk region was carried out. The results of this study help to substantiate the composition of specialized agricultural production zones (growth poles) in the Western macro-district. 
In Table 2, the natural-climatic and soil features for the territories of the Western macrodistrict are highlighted. Considering its administrative boundaries, it was possible to distinguish the contours of the border for the Western agro-industrial zone of the Krasnoyarsk region.

Table 2. Features of the Western agro-industrial zone.

\begin{tabular}{|l|l|l|}
\hline $\begin{array}{c}\text { Name and } \\
\text { territorial } \\
\text { structure of the } \\
\text { zone }\end{array}$ & \multicolumn{1}{|c|}{$\begin{array}{c}\text { Natural-climatic and soil } \\
\text { features }\end{array}$} & $\begin{array}{c}\text { Prospective areas of } \\
\text { agricultural } \\
\text { specialization }\end{array}$ \\
\hline $\begin{array}{l}\text { Birilyuss- } \\
\text { Tyukhtetsk- } \\
\begin{array}{l}\text { Bolsheuluisk } \\
\text { subzone (north of } \\
\text { the zone) }\end{array}\end{array}$ & $\begin{array}{l}\text { Lowland subtaiga and forest- } \\
\text { steppe. The predominance of } \\
\text { podzolic and sod-podzolic } \\
\text { soil. }\end{array}$ & $\begin{array}{l}\text { Specialized zone of } \\
\text { forestry and secondary } \\
\text { types of forest } \\
\text { management (forestry, } \\
\text { beekeeping, mushroom } \\
\text { and berry picking). }\end{array}$ \\
\hline $\begin{array}{l}\text { Bogotol-Achinsk- } \\
\text { Kozulka subzone } \\
\text { (center of the zone) }\end{array}$ & $\begin{array}{l}\text { Lowland subtaiga combined } \\
\text { with island forest-steppes. } \\
\text { The predominance of gray } \\
\text { forest soil. }\end{array}$ & $\begin{array}{l}\text { Specialized zone of } \\
\text { suburban vegetable } \\
\text { growing, poultry farming } \\
\text { and dairy and meat cattle } \\
\text { breeding. }\end{array}$ \\
\hline $\begin{array}{l}\text { Sharypovo- } \\
\text { Nazarovo subzone } \\
\text { (south of the zone) }\end{array}$ & $\begin{array}{l}\text { Island forest-steppe } \\
\text { combined with lowland } \\
\text { subtaiga. The predominance } \\
\text { of podzolized and leached } \\
\text { chernozems. }\end{array}$ & $\begin{array}{l}\text { Specialized area of grain } \\
\text { production, their high- } \\
\text { tech processing and dairy } \\
\text { and meat cattle breeding. }\end{array}$ \\
\hline $\begin{array}{l}\text { Uzhursk- } \\
\text { Novoselovo } \\
\text { subzone (south of } \\
\text { the zone) }\end{array}$ & $\begin{array}{l}\text { Island forest-steppe } \\
\text { combined with lowland } \\
\text { subtaiga. The predominance } \\
\text { of chernozems of ordinary, } \\
\text { southern and chestnut soils. }\end{array}$ & $\begin{array}{l}\text { A specialized area for the } \\
\text { production of grain and } \\
\text { dairy-meat cattle } \\
\text { breeding. }\end{array}$ \\
\hline
\end{tabular}

The spread of gray forest soils and lowland subtaiga in the north of the Western macrodistrict creates favorable conditions for the specialization of the Birilyuss, Tyukhtetsk, Bolsheuluisk municipal districts in dairy and meat cattle breeding based on their own feed base. In the territories of the listed municipal districts, there are also favorable conditions for the development of forestry and secondary types of forest use: the collection and processing of berries (cranberries, raspberries, strawberries), pine nuts, mushrooms, wild herbs (meadowsweet, cypress, sage, fern, wild cherry, etc.).

The predominance in the center of the zone - in the Bogotol and Achinsk municipal districts of gray forest soil, lowland subtaiga, combined with island forest-steppes and the presence of large cities (Achinsk, Bogotol), creates favorable conditions for the formation of a specialized zone of suburban vegetable growing, poultry farming and dairy-meat cattle breeding [20-24].

In the south of the Western agro - industrial zone in the Sharypovo and Nazarovo municipal districts, forest-steppes in combination with lowland subtaiga are widespread, where podzolized and leached chernozems predominate. Considering the natural-climatic and soil features of these areas and the presence of urban districts - the cities of Nazarovo and Sharypovo, it should be recognized as prospective to form the following specialized zones of the agro-industrial complex:

- specialized area for the production of cereals and products of their high-tech processing (production of lysine, feed protein additives);

- specialized areas of poultry and meat-and-dairy cattle breeding based on their own feed base.

The chernozems predominance of ordinary, southern and chestnut soils in the Uzhur and Novoselovo municipal districts favors the formation of the following specialized zones in these territories: 
- specialized zone of grain production (food wheat);

- specialized zone of dairy and meat cattle breeding.

\section{Conclusions}

1. The decline in the number of rural settlements and their size in the region, the decline in the birth rate and incomes of the rural population, the continued dependence of the Krasnoyarsk Territory on the import of a number of food products are the result of unsustainable placement and development of agriculture. Some of the key causes of these problems are:

- unsustainable, inadequate use of natural-climatic, socio-economic prerequisites in the location and development of agro-industrial enterprises in the region;

- insufficient attention to the formation of rational specialization and division of labor, economic ties between territories.

The solution of these problems is possible as a result of the implementation of a special strategy for spatial development of the region. Its measures should take into account the economic validity of the formation in the region of the territorial framework of the regional agro-industrial complex in order to increase the rationality of the deployment of productive forces. It is necessary to develop the infrastructure of intermediate territories between growth poles. By them we mean specialized centers of agricultural production, which produce a variety of food products.

2. In the conditions of a market economy, the formation of rational specialization and interdistrict economic relations that ensure the most effective use of territorial social, naturalclimatic, and economic-geographical prerequisites for the development of rural territories becomes relevant. It is necessary to have a uniform, differentiated development for the territories of the Western macro-district based on the formation of the territorial framework of the agro-industrial complex. It is necessary to develop the transport infrastructure, the migration and the shift method of attracting qualified labor resources for the period of the sowing and harvesting campaign in rural areas.

3. To attract human resources and preserve them in rural areas, it is necessary to create a favorable social environment. It is necessary to develop kindergartens, schools, leisure centers, and the public health system. The solution to this problem will contribute to the formation of a high culture of rural lifestyle, preservation and qualitative improvement of agroclimatic resources. These tasks should be solved by attracting the labor of volunteers on the principles of corporate volunteering for the implementation of projects for the socioeconomic development of the productive forces of the agro-industrial complex. It is relevant to attract the volunteer initiative of the most developed part of schoolchildren, students, pensioners of cities and rural settlements. This form of interaction will contribute to the transfer of the values of creation, innovation from the most creative part of volunteers to rural residents to help their self-realization on the ground. The implementation of these initiatives should have a beneficial effect on reducing the outflow of the rural population, strengthening the socio-cultural, demographic and labor potential of specialized agricultural production centers.

\section{References}

1. S. Achten, World development, 136 (2020)

2. J. Boudevill, Promlems of regional economic planning (1966)

3. M. E. Porter, The Competitive Advantage of Nations (1990)

4. A. Lesh, Geographical location of the farm (1959) 
5. F. Perrous, Leconomia du $x x$-eme siecle (1961)

6. I.G. Tyunen, The isolated state (1926)

7. V.V. Kistanov, N. V. KopylovRegional economy of Russia (2006)

8. R. I. Schnipper, Region: economic management methods (1991)

9. A. I. Altukhov, Applied economic research, 5(27) (2018)

10. M. L. Vartanova, P. K. Gazimagomedova, Food policy and security, 5(3) (2018)

11. V.G. Kryuchkov, Use of land and food resources (1987)

12. L. P. Silaeva, Scientific review: theory and practice, 1 (2016)

13. I. N. Merenkova, Sustainable development of rural territories: theory, methodology and practice (2011)

14. A.V. Rozhkova, E.V. Stepanova, Int. Conf. on Efficient Production and Processing (ICEPP-2020), 161, 01086 (2020)

15. O.V. Zinina, N. A. Dalisova, J. A. Olentsova, IOP Conf. Ser.: Earth Environ. Sci., 548, 022028 (2020)

16. A. A. Belousov, E. N. Belousova, E.V. Stepanova, IOP Conf. Ser.: Earth Environ. Sci., 421, 032001 (2020)

17. G. Belyakova, E. Stepanova, E. Zabuga, 20th European Conf. on Knowledge Management (ECKM), 1 (2019)

18. O. A. Nezamova, J. A. Olentsova, Int. Conf. on Efficient Production and Processing (ICEPP-2020), 161, 01080 (2020)

19. A. V. Rozhkova, J. A. Olentsova, Int.l Conf. on Efficient Production and Processing (ICEPP-2020), 161, 01086 (2020)

20. D. S. Shalaeva, O. I. Kukartseva, V. S. Tynchenko, S. V. Aponasenko, E. V. Stepanova IOP Conf. Series: Materials Science and Engineering, 952(1), 012025 (2020)

21. A. V. Rozhkova, N. A. Dalisova, E. V. Stepanova, M. V. Karaseva, IOP Conf. Ser.: Earth Environ. Sci,. 421, 082020 (2020)

22. M. G. Ozerova, A. V. Sharopatova, IOP Conf. Ser.: Earth Environ. Sci., 548, 22051 (2020)

23. M. G. Ozerova, A. V. Sharopatova, IOP Conf. Ser.: Earth Environ. Sci., 677, 22082 (2021)

24. S. K. Shardan, N. B. Davletbayeva, S. S. Morozkina, D. Sh. Musostova, A.V. Sharopat ova, AD ALTA: J. of Interdisciplinary Research, 10(2) (2020) 